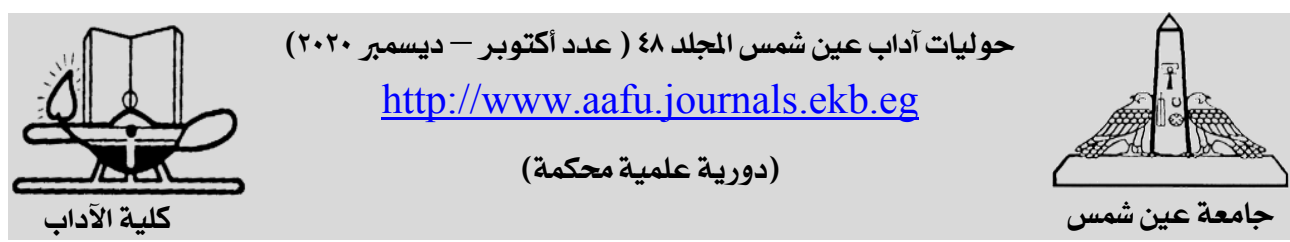

\title{
Teeth in Ancient Egyptian Religious Texts
}

\section{Rania Abdel Aziz Mahmoud*}

Lecturer, Fayoum University, Faculty of Archeology

\begin{abstract}
:
The mouth is one of the most important body members, as it receives food, drinks, speech and sense. The opening of the mouth rite was one of the most important and most significant rites known to the Ancient Egyptians.

Teeth were among the most important parts mouth having great significance to the Ancient Egyptian. Many words have expressed these ideas and have taken the elephant tusk as a determinative.

The Ancient Egyptian used the animal tusks such as those of the elephant, hippopotamus in different industries such as amulets, make up and primitive drugs.

The religious symbolism of teeth varied from pyramid texts to coffin texts and books of the dead. The mouth of the deceased was provided with teeth of Horus with onion offerings. His sharp teeth were described as the teeth of the immortal god "Soped". In addition, the teeth of the deceased king were the souls of "ba" and they were obtained from the viper hill " $\underline{d} w . f t$

In CT, the deceased was given strong sharp teeth made of flint stone made of the material of stars. His sharp teeth enabled him to be embodied and appearance as the god "Sobek".

In the Book of the Dead, the deceased declared his ownership of sharp teethlike the god "srkt"and canines like the holy goddess Isis. The glitter in his teeth and its beauty is due to his being a member of Fayoum city.
\end{abstract}

Keywords

Mouth- teeth - PT- CT- BD- Soped- srkt- Isis

جميع حقوق الطبع والنشر محفوظة لحولية كلية الآداب - جامعة عين شمس •r.r. (T. 


\section{Introduction}

The human body had great holiness for the Ancient Egyptian reflected in many rites special for reviving him through rites of protecting all his body members. $^{(1)}$

The mouth is among the most important human body members where its function was represented in receiving food, speech and expression of sense $^{(2)}$.

The opening of the mouth rite known in the ancient Egyptian language as $\mathrm{I} w p t-r^{(3)}$ is considered one of the most important and famous rites in the Ancient Egyptian religion ${ }^{(4)}$. The opening of the mouth rite took place on a statue representing the deceased or the mummy of the deceased himself ${ }^{(5)}$ by reviving the senses of the deceased starting from the revival of the mouth through this rite. ${ }^{(6)}$ It was originally performed on statues of gods, then became performed on all the deceased, whether kings or individuals, in addition to being performed on miniatures used for the purpose of magic ${ }^{(7)}$, such as: the scarab of the heart and other amulets ${ }^{(8)}$. It was also performed on some sacred animals, such as the calf $\mathrm{Abis}^{(9)}$. Moreover, it was performed for temples, where they replace the gods in their images and form engraved on walls. Thus, the offerings presented to them are offered. ${ }^{(10)}$

Some words signifying some mouth parts were used in ancient Egyptian texts such as:

Since the era of the Old Kingdom, the word I $\triangle r^{3}{ }^{(11)}$ was used to express the mouth or wisdom, speech and language. ${ }^{(12)}$ And since the era of the Middle Kingdom it was used in the form of $\propto$, and New Kingdom, it appeared in the forms of $\sum_{0}^{11} 0,10$, mmm It was used to express the bill/ beak of birds and animal mouths ${ }^{(13)}$.

In addition, some words were used to express some mouth parts in Egyptian texts.0

Since the era of pyramid texts, the word spty was used ${ }^{(14)}$ in the form of $\vec{D}$ and in the era of the Middle Kingdom in the form of $\vec{\square} \square$, as well as in the era of the New Kingdom in the form of $\square$ II and with the determinatives

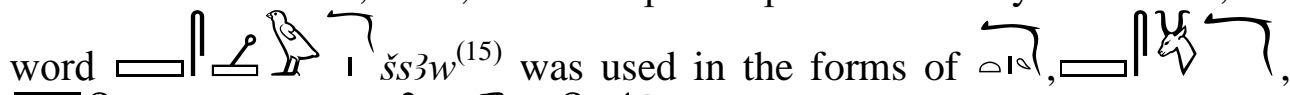
L 2 and in the forms of the forms of to express the tongue since the Pyramid texts in the forms of 

$t^{(18)}$ since the era of the Middle Kingdom in the forms of mmm $S$

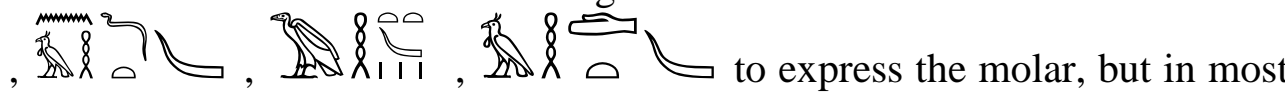

cases it also expresses teeth. The two words used the determinative

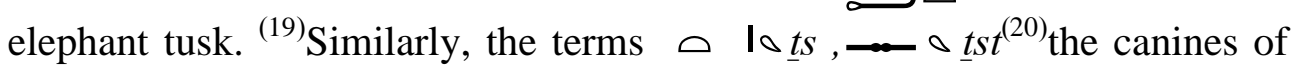
the hippopotamus and pieces of ivory were used since the era of Naqqada I with dots and semi geometric engraved borders and other zigzag line. They made a deep border for each of them surrounding its upper part nearly dividing it to two parts: a small upper part representing the head, and a big lower part representing the body. In a museum in the university college in London, there is a big set of these tusks ${ }^{(21)}$ that the great scientists predict are amulets used whether for those living or dead. ${ }^{(22)}$ In this explanation, the scientists depend on a hole being at the top of some of these tusks ${ }^{(23)}$.In contrast, some others suggested that these tusks ${ }^{(24)}$ were used in preserving the makeup powder and primitive pharmaceutics that can be extracted from nature and from these canines and used. Randalle suggested that they represented part of magicians' tools, or they might have been used by dancers in performing their dances then. ${ }^{(25)}$

Most of these tusks were distributed on some European museums ${ }^{(26)}$, such as the Ashmolean Museum in Oxford ${ }^{(27)}$ and Berlin museum. The opinions of scientists differed about the dating of these tusks. Most opinions are unanimous about them being from the era of Naqqada I ${ }^{(28)}$.

\section{Aim of the research}

Signifying the role of teeth in the hereafter and their relationships to the gods, as there is no separate study for their roles. Thus, the scholar consulted several references which are:

- Sethe.k., Die Altägyptischen Pyramidentexte, 4 Bde, Leipzig 1908-1922.

- Faulkner, R.O., Ancient Egyptian Pyramid Texts, Oxford, 1969.

- Mercer, A.A., Pyramid Texts , Commenter, Vol. II , 1952.

- Allen , J.P., The Ancient Egyptian pyramid Text, Society of Biblical Literature, Atlanta , 2005.

- Carrier, C., Textes Des Pyramides de L'Egypte Ancienne, Tome VI , Cybele, 2010.

- Budge, W., Book of the Dead , 3 vols , London, 1910.

- Faulkner, R.O., Ancient Egyptian Coffin Texts , 3 vols, Warminster, 1973-1978. 


\section{Teeth in pyramid texts}

The religious symbolism of teeth varied in pyramid texts where the mouth of the deceased is supplied with the white teeth of Horus with five pots of onion. The teeth of the deceased were depicted as the teeth of immortal "Soped" with sharp teeth. The teeth broke the stone due to its extreme strength. In addition, the king's teeth were in alba souls. Moreover, the deceased king's teeth Osiris come from the viper mountain "d $w . f t$ ".

Starting with spell " 45 " of the pyramid texts, the deceased king is supplied the white teeth of Horus with 5 pots of onion ${ }^{(29)}$.

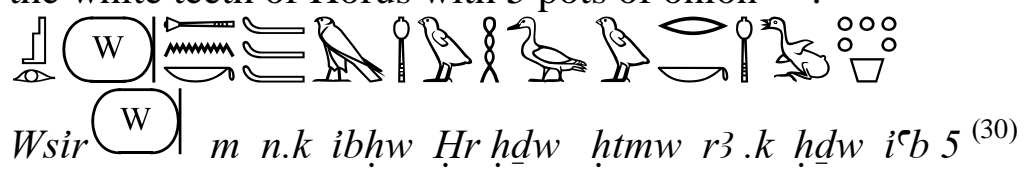

"It is he Osiris the King take the white teeth of Horus for you to supply your mouth with, five pots ${ }^{(31)}$ of onion" (32)

Roth thinks ${ }^{(33)}$ that the offering presented with the teeth is the garlic not onion, and that the clove of garlic when peeled resembles the teeth more than green onion. He said that there is resemblance between dentition in children and presenting garlic, as the deceased when revived again becomes like the newborn, so he must pass by the dentition stage until he eats solid food. So, the aim of presenting garlic in the opening of the mouth rite is achieved. In contrast, Hassan thinks that this offering is $h \underline{d} w$ "onion"(34) . Barta sees that it is onion, and thinks it is an appetizer ${ }^{(35)}$.

Ghalioungui believed that presenting onion was linked to resurrection of the deceased, as it makes the deceased breathe once more ${ }^{(36)}$.

The concept itself is repeated from presenting onion with the teeth of the deceased Osiris in spell 125 where the following appeared ${ }^{(37)}$ :

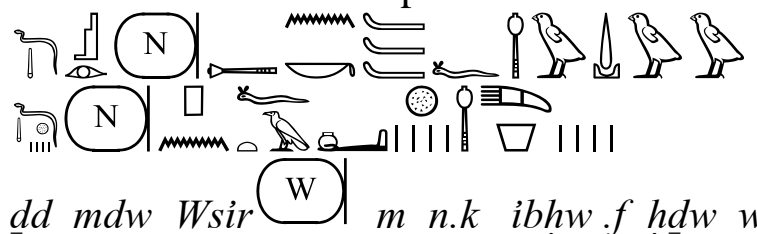

hnk sp4 $h \underline{d} \underline{d} w \quad i c b 4^{(38)}$

"Recitation: O Osiris I bring to your healthy white teeth a four-time recitation; O King $\mathrm{N}$ a presentation; four times pots of onions"(39)

In spell 215, his head resembles the head of $\mathrm{Hr}-\mathrm{Dw} 3 t$, his face resembles the face of mhnty irty ${ }^{(40)}$, his ears are the ears of the son of Atom "the twins", his eyes are the eyes of sons of Atom, and his nose is the nose of the jackal. As for his teeth, they are the teeth of "Soped" the imperishable ${ }^{(41)}$. The spell refers in passage 148 to the following ${ }^{(42)}$ :

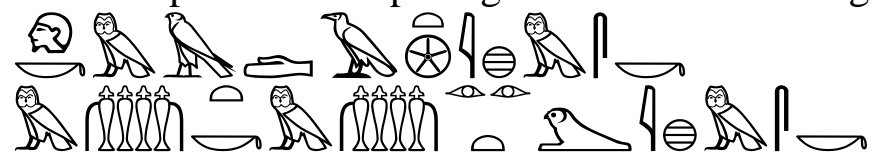




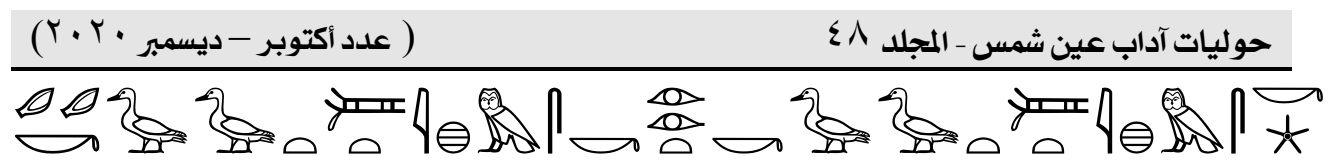

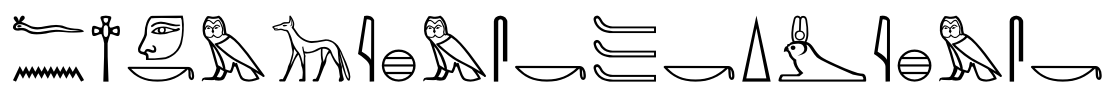

tp.k $m \mathrm{Hr}$-dw3t ihm-sk mhnty.k mhnty-irty ihm-sk msdr.wy .k s3ty Tm ihm-sk irty.k s3ty Tm ihmm-sk sb3w fnd.k m s3b ihmm-sk $i b h w . k(m)$ spd $i h m-s k^{(43)}$

"Your head is $\mathrm{Hr}-d w 3 t, \mathrm{O}$ imperishable, your face is (the face) of mhnty - irty O imperishable, your ears are (the ears) of the son of "Atum" the twins O imperishable; your eyes are the eyes of the son of "Atum" the twins $\mathrm{O}$ imperishable stars; your nose is the nose of the jackal $\mathrm{O}$ imperishable; your teeth are the teeth of "Soped" O imperishable"(44).

The same meaning is repeated in spell 222 in passages 201-202 as follows ${ }^{(45)}$ :

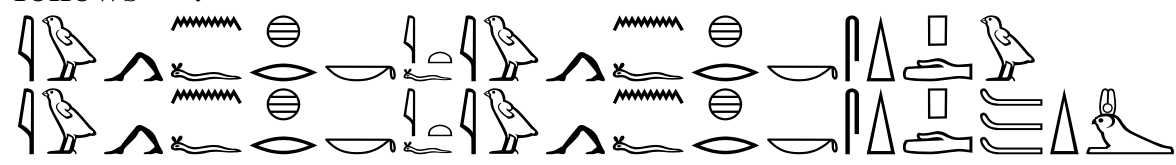

iwn.f hr.k it. (f) iwn.khr.k spdwiwn.fhr .k it (f) iwn.fhr.k spd-ibhw ${ }^{(46)}$

"I came to you "Soped", I came to you, O you with sharp teeth" (47).

In this spell, "Soped" is truly described as having sharp teeth. Here, his role is related to his being a god of protection, as he is an Asian god protecting the East and protecting the border areas like the turquois mines in Sinai ${ }^{(48)}$. And thus, the deceased acquires the same characteristics as sharply teethed like "Soped".

In the events of spell 436, he possesses the power that makes him break the stones with his teeth and nails when he goes as a follower for "Osiris", and grants him perfume of the goddess "iht-wtt. In passages 790791 the following occurs ${ }^{(49)}$ :

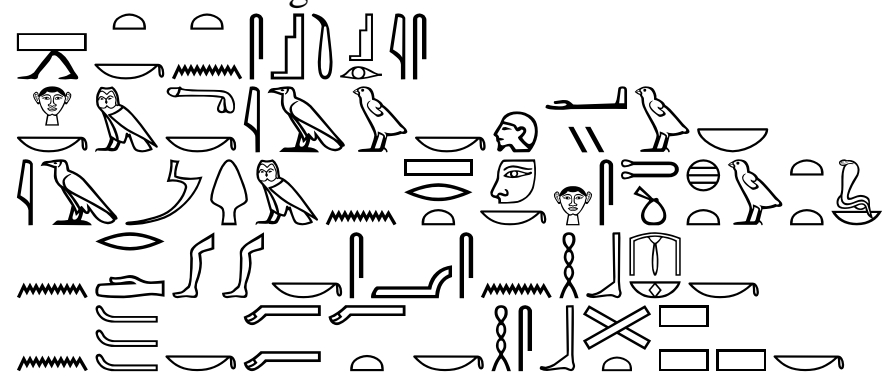

šmt.k th sti wsir is hr .k $m$ b3h.k $i 3 w . k$ tp- ${ }^{\top} w y . k^{\text {sic }} i 3 m . w n s ̌ r t$ .$k$ hr sti iht-wt.tn rdwy.k skr.sn hb.k $n$ ibhw.k ‘nwt.k hsb.t inrw ${ }^{(50)}$

"Your walk is the follower (back) of Osiris, your face in front of you, your prayers in front of you, the kindness (sweetness) for your nose because of the perfume of "iht-wtt" and for your feet when you step out of the place of your celebrations for your teeth and nails when you break the stones ${ }^{(51)}$." 
The scholar believes the power possessed by the deceased to break the stones emerged from the perfume "iht-wtt"; this goddess that possessed a scent that helps the refreshment of the body, and with her ability transfers the deceased from one place to another. Thus, the deceased possessed the same abilities of this goddess viper. ${ }^{(52)}$

In addition, he was embodied in the Osirian image which links the teeth to the events of the Osirian legend. It was earlier pointed out that the deceased possessed Horus's strong teeth.

In addition, the events of spell 539 of the pyramid texts to a new meaning as the king's teeth represent "ba" souls ${ }^{(53)}$ so that he can ascend to heaven, where the following is mentioned ${ }^{(54)}$ :

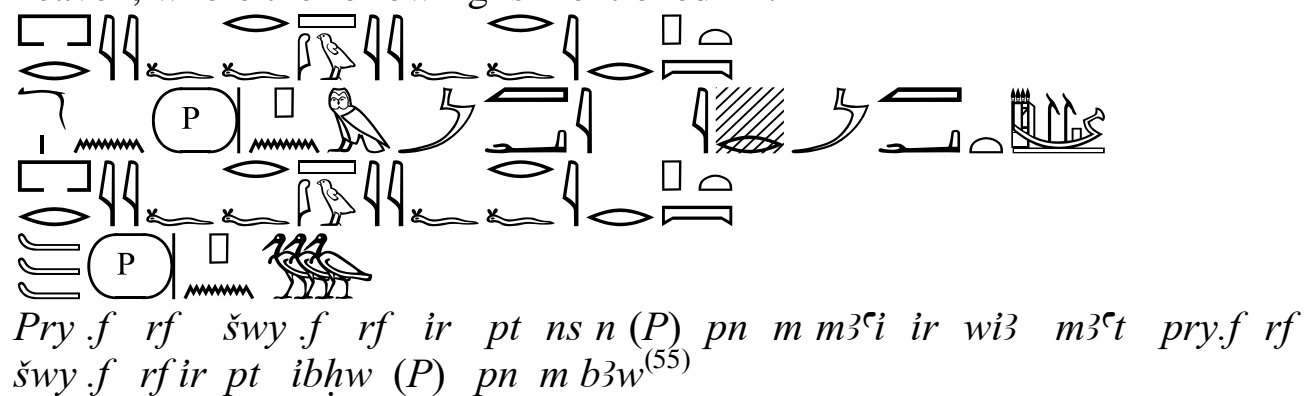

"He is emerging and ascending to heaven and the tongue of this king (P) is the (leader) of the boat $m 3^{\top} t$ that he emerges and ascends to heaven, the teeth of this king are souls of $b 3 w^{\text {"(56) }}$

In merging with the Osirian legend events, the image of the deceased Osiris follows King Osiris and becomes blessed with bread ${ }^{(57)}$ and beer ${ }^{(58)}$, as his white teeth are from the viper mountain" $\underline{d} w . f t^{\prime \prime}(59)$. Passages $1357-$ 1359 refer to the following ${ }^{(60)}$ :

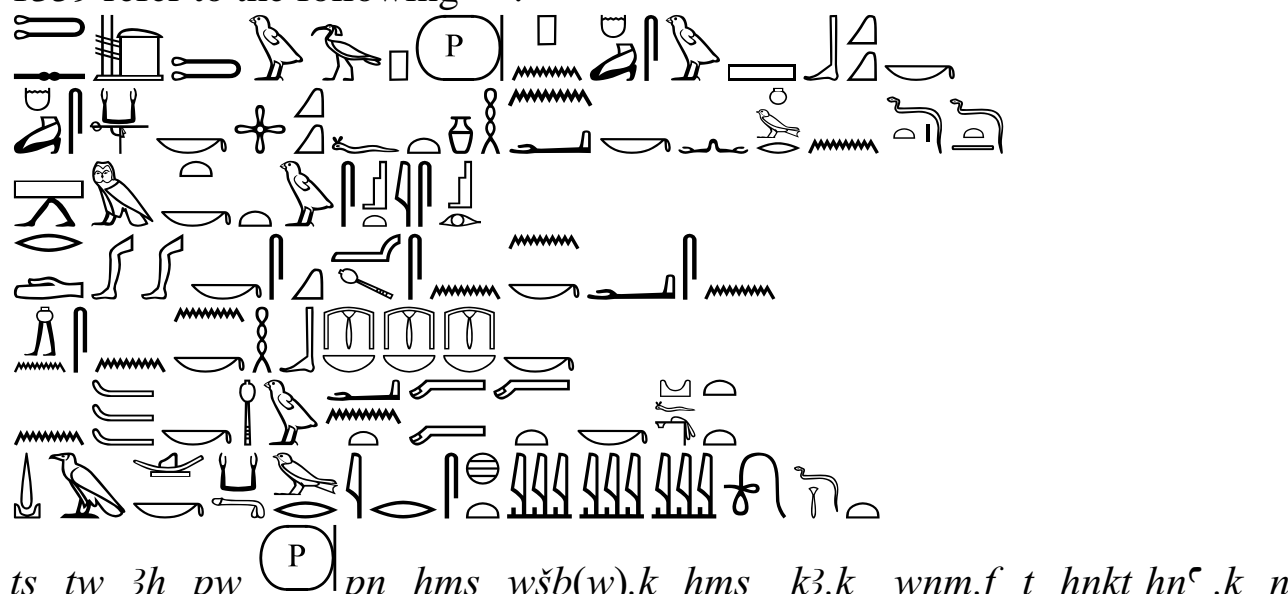

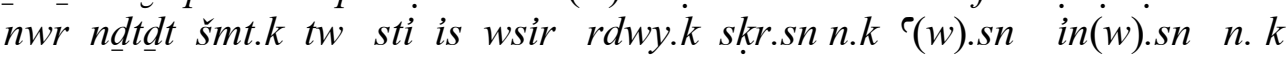
$h b w . k \quad n \quad i b h w . k \quad h \underline{d} w$ ' $n . w t . k \quad(m) \underline{d} w . f t \quad \underline{d} 3 . k \quad k 3-w r i r \quad s h w t$ $w 3 \underline{d} t^{(61)}$

"Raise yourself, $\mathrm{O}$ soul of (Akh) this king $\mathrm{P}$ and sit and eat your 
meal, may be your (ka) will sit and eat bread and beer non-stop forever. You go like the follower of Osiris;your feet step outwards and their arms bring for you your feasts because your white teeth and your nails are of the viper mountain $\underline{d} w$.ft. May you cross, O Great Bull, to the green fields “(62)

Spell 659 of the PT directs the speech to the deceased king, asks him to receive his white teeth and revolve around them with an arrow between them. It refers to the following ${ }^{(63)}$ :
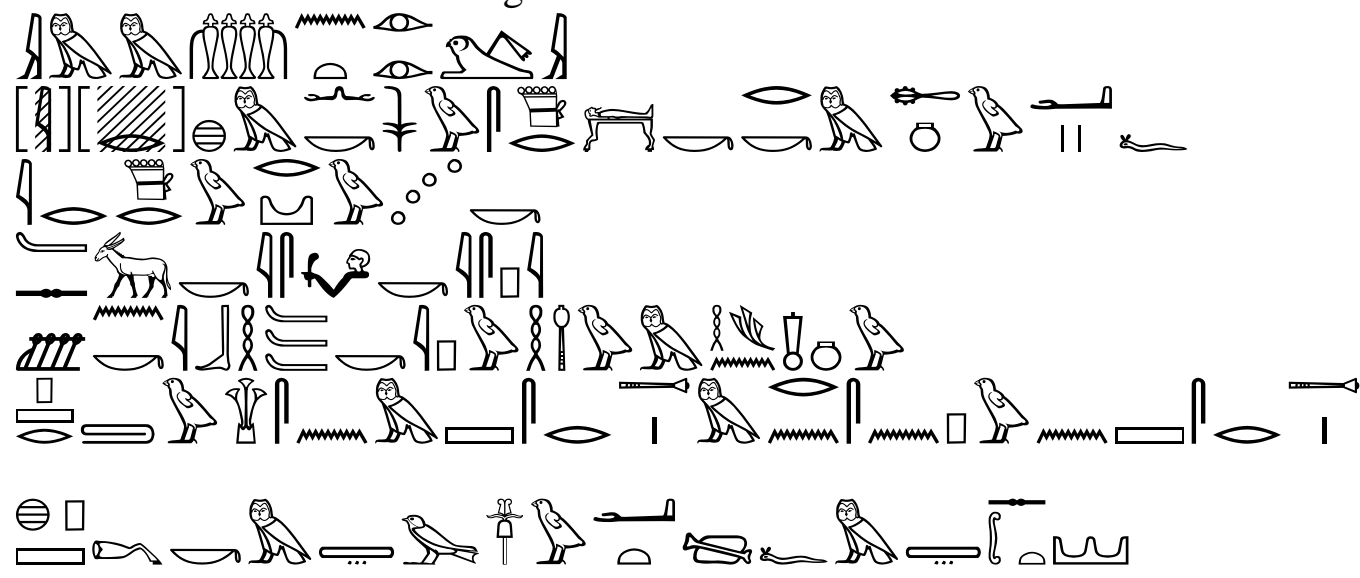

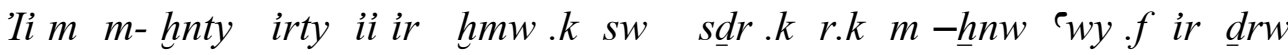
$r d w . k$ bhs. $k$ is mniw.k is pi šsp $n . k$ ibhw.k ipw hdw $m$ hnw pw

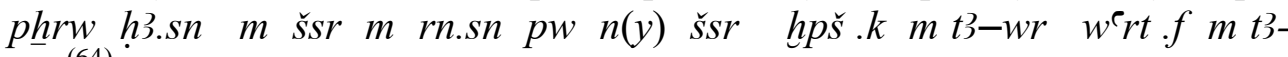
sty ${ }^{(64)}$.

"hnty-irty came if you do not know him, and you will lie down (sleep)in his arms (in his bosom) until he stops his efflux as your calf for he is your herdsman; receive your white teeth in this jar; revolve around them with an arrow in their names is that arrow; and that your front (limbs) are ${ }^{(65)}$ in $t 3-w r$ "Abydos" (66) and your hind limbs are in $t 3-s t i$ (Nubia) ${ }^{(67)}$."

Mercer comments about revolving around the jar containing the teeth with an arrow that he is describing a game called "the viper" because the word " $m h n "$ is one of the names of the viper mountain ${ }^{(68)}$.

\section{Teeth in coffin texts}

Teeth had important significance and symbolism in coffin texts, where the deceased cleanses himself and cleans is teeth to cross heaven and pass it. In addition, the deceased was able to obtain strong sharp teeth made of flint and canines from the viper mountain " $\underline{w} w . f t$ ". In coffin texts, there was reference to the teeth of the deceased being made of star metal.

Here, the study starts with spell 173 which refers to the following ${ }^{(69)}$ :

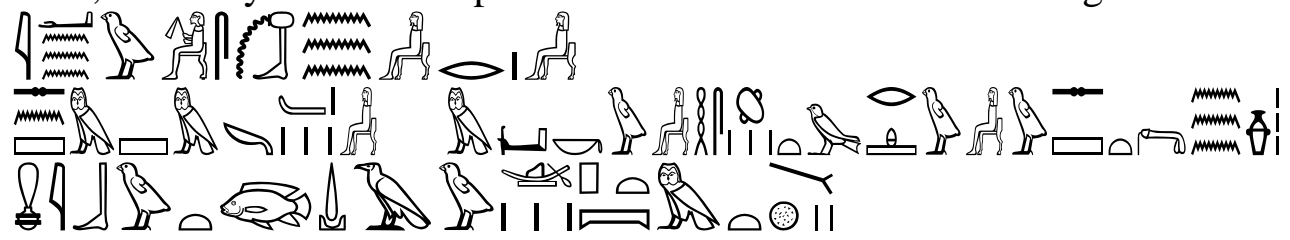

'I wi.i sweb.i r\}.i snšmšm(w) ibhw.i mk wi hs twr wi wsšt mi bwt d3w.wt pt $\quad$ mwt $s p 2^{(70)}$ 
"I clean myself and cleanse my mouth and sharp teeth, feces protect me, and urine respects me like the scary (horrible) heaven crossers, the dead said twice" (71)

In the events of spell 342, there appeared what shows that the deceased has teeth of flint stone and canines from the viper mountain " $d w . f t$ " as it refers to the following ${ }^{(72)}$ :

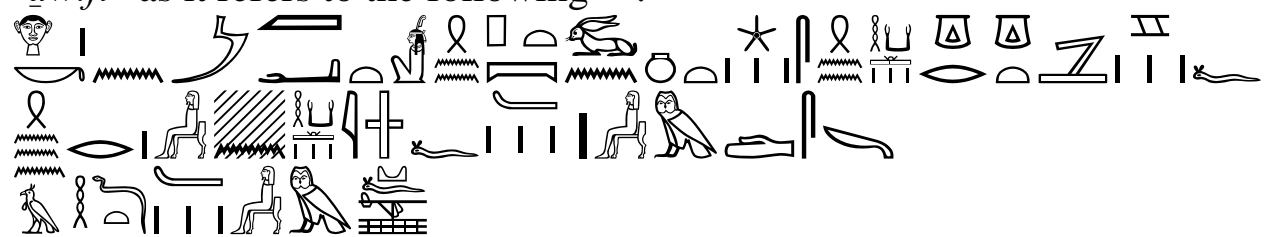

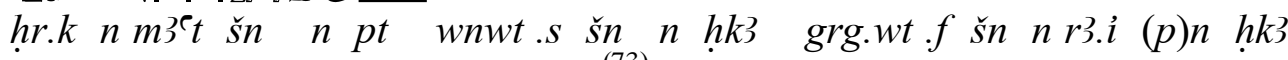
imy. fibhw.i $m$ ds $n h \underline{h} \underline{d} w t . i \quad m \underline{d} w . f t^{(73)}$

"Your face is towards truth (justice); heaven is surrounded by its stars and magic surrounds the kingdoms (lands); my mouth surrounds magic that is in it, my teeth are made of Flint and my canines of $\underline{d} w . f t^{(74)}$."

In the events of spell 666 of coffin texts, there is a description of the deceased who obtained teeth, closed under him, made of heaven star metal, in reference to extreme strength ${ }^{(75)}$ :
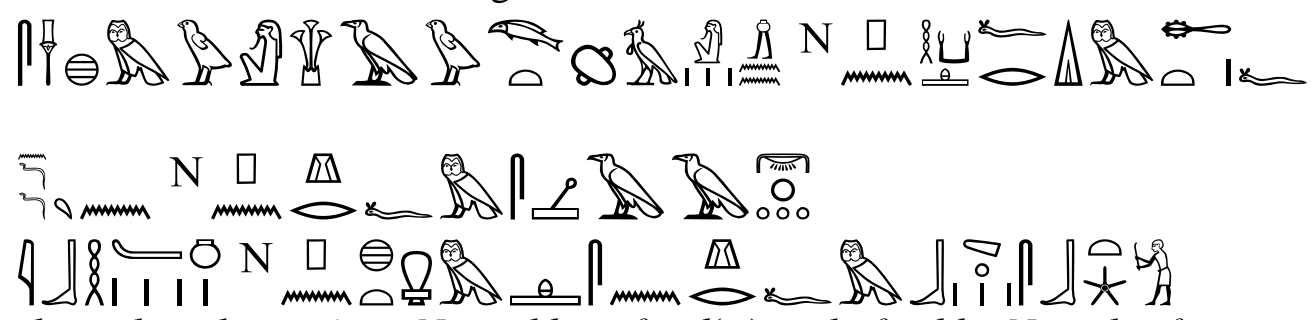

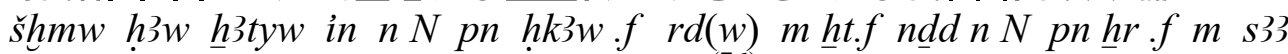
$i b h w n w N p n$ htm .sn $\underline{h r}$.f $\dot{m}$ bi3 sbty ${ }^{(76)}$

O strong people, those who are behind those specialized in the body; this deceased $N$ has brought magic (dormant) in the body; it is being placed in part of the body of the deceased $N$ which is under him made of electrum; the teeth of this deceased $N$ is (complete) closed under him from the star metal $^{(77) \text {, }}$

As it appeared in the events of spell 991 of the coffin texts, there is reference to his teeth in the hereafter being made of metal. By destroying them, he obtains this strength and sovereignty that carries him by embodying the image of Sobek, where the following appeared in $\mathrm{it}^{(78)}$ :

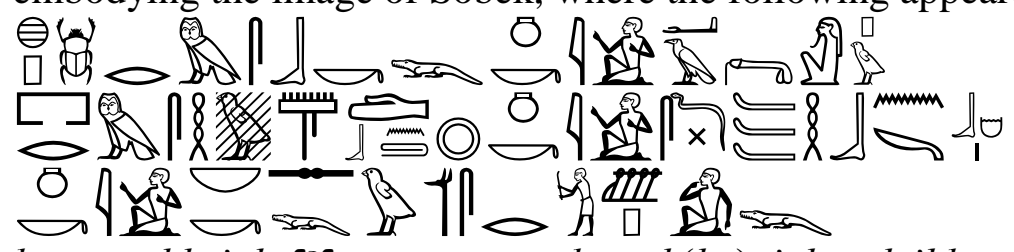

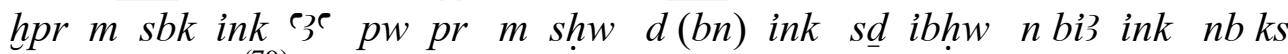
wsr šsp $m s h^{(79)}$ 
"Appearance like Sobek, it is I the seed, that exits from the encircling wrappings; it is I the destroyer (breaker) of teeth made of metal; I, the master of strength and the strong being embodied in the image of the crocodile". ${ }^{(80)}$

The same concept is repeated in spell 1011, where the deceased mentioned that he is cleansed, teethed and strong mouthed, and that he hates isft "evils", ${ }^{(81)}$ where the spell refers to the following ${ }^{(82)}$ :

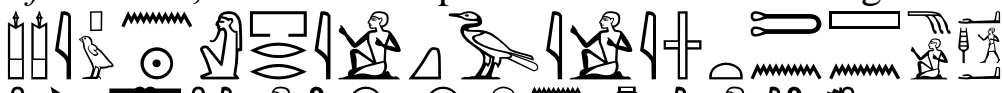

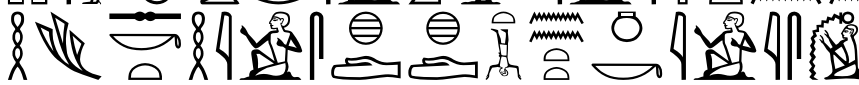

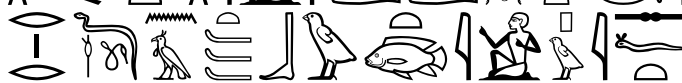

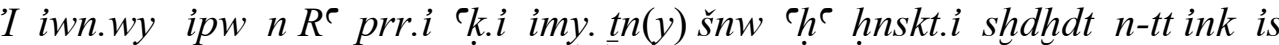
$w^{\top} b r 3$ rwd $n h \underline{d} w t b w t . i$ pw isft $t^{(83)}$

"O two columns of Re, I am ascending, and entering between you; my hair is standing, my braids are hanging because my mouth is cleansed; I am strongly teethed (canines) and what I hate is "isft $t^{(84) \text { " }}$

\section{Teeth in the Book of the Dead}

The previous concepts were widely repeated where the deceased becomes proud of his sharp teeth being made of flint and canines from viper mountain " $d w . f t$ ". He also possesses the teeth of goddess "srkt and the canines of the holy goddess Isis. He also possesses sharp teeth and canines as the canines of snake $m h n$. The deceased attributed himself to the city of Fayoum as he possesses white teeth.

The study starts in chapter 31 of the Book of the Dead, where his passages refer to the following ${ }^{(85)}$ :
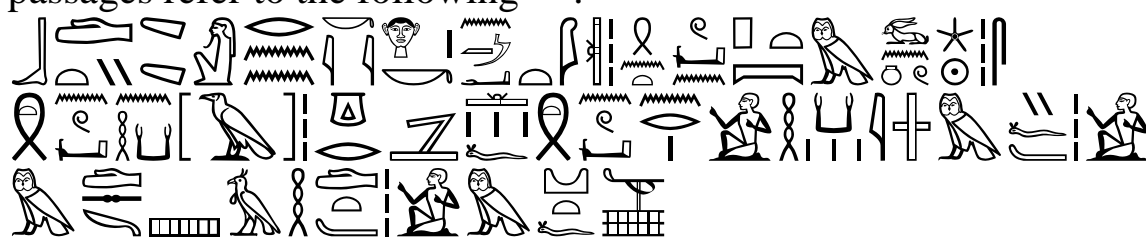

Bdty $r n n$ ky hr.k $n$ m3`t šnt $n$ pt $m$ wnwt.s šn $n h k 3(m)$ grg.f šn $n$

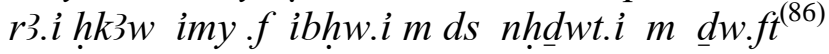

"Bdty is the other name; your face is $m 3{ }^{\top} t$; heaven was surrounded by its stars; magic has surrounded the lands (kingdoms). My mouth has been surrounded by magic inside it; my teeth are made of flint and my canines are made of the viper mountain " $d w . f t^{\prime \prime(87)}$

And in Ch. 42 of the Book of the Dead, the deceased compared his teeth to the teeth of srkt and his canines to the canines of holy Isis. The chapter refers to the following ${ }^{(88)}$ :

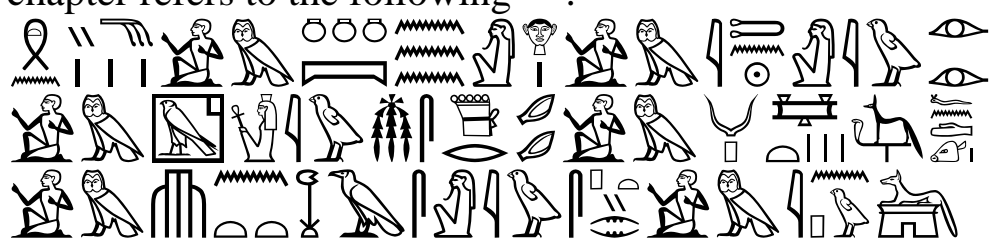


šn .i $m$ Nw.w hr.i $m$ ịtn iw ir.ty $m$ Ht $-h r$ iw msdrw.y $m$ wp-w3wt fnd.i

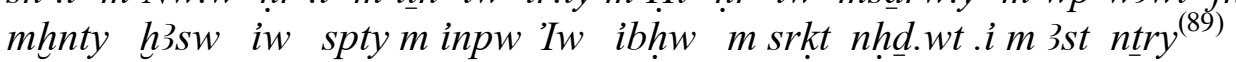

"My hair is the hai nr of "Nw.w"; my face/is the sun disc. My eyes are " $H t-h r$ ". Myears are $w p-w 3 w t$ "; My nose is "mhnty $h 3 s w " .{ }^{(90)}$ My lips are "inpw"; my teeth are"srkt"; my canines are holy Isis. ${ }^{(91)}$

"srkt" was one of the gods of protection ${ }^{(92)}$. She participates with Isis in being one of the goddesses that protect the four members. Thus, the deceased's comparison of his teeth to the teeth of "srkt" and canines of Holy Isis announces his desire to be embodied in the images of the protective goddesses, thus owning sharp teeth that enable him to attack the enemies.

In the passages of Ch. 172 of the Book of the Dead, the deceased looked like the snake " $m h n^{\prime}{ }^{(93)}$ in the sharpness of his teeth. To get this meaning, the chapter refers to the following: ${ }^{(94)}$

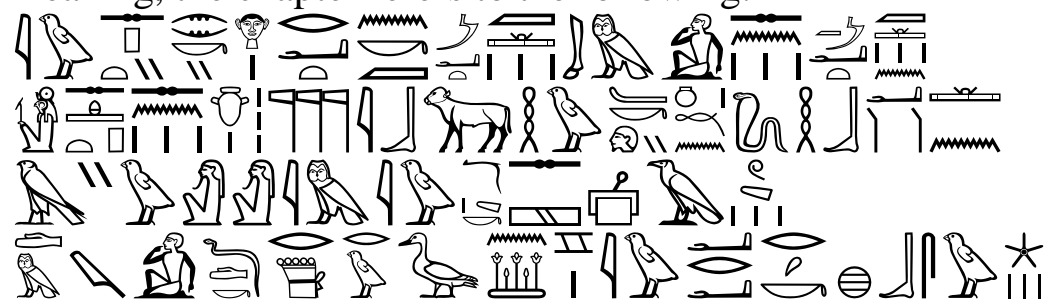

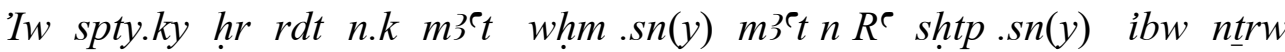
ibhw.k tpy $n w$ mhn $n$ hb $b^{\odot} n$ Hrwy im iw ns.k šs $3 w d m \underline{d d} . k$ r dry.wt $n$ $\check{s} \dot{i} w^{C} r^{\top} r . k \underline{h} 3 b 3 s w^{(95)}$

"your lips give you the truth - repeat the truth to Ra and calm the hearts of the goddesses; your teeth are those of $m h n$ (the snake $m h n$ ) with which the two Horus play with, a wise (careful) sharp tongue when it talks to the kite of the swamp, and your jaw is heaven studded (decorated) (with stars) $)^{(96)}$.

Moreover, the passages of chapter 189 of the Book of the Dead are the same as passages of chapter 52 of the same book in that the deceased will receive his teeth with a mixture of perfume as a type of offerings that he obtains in the hereafter. The passages refer to the following ${ }^{(97)}$ :

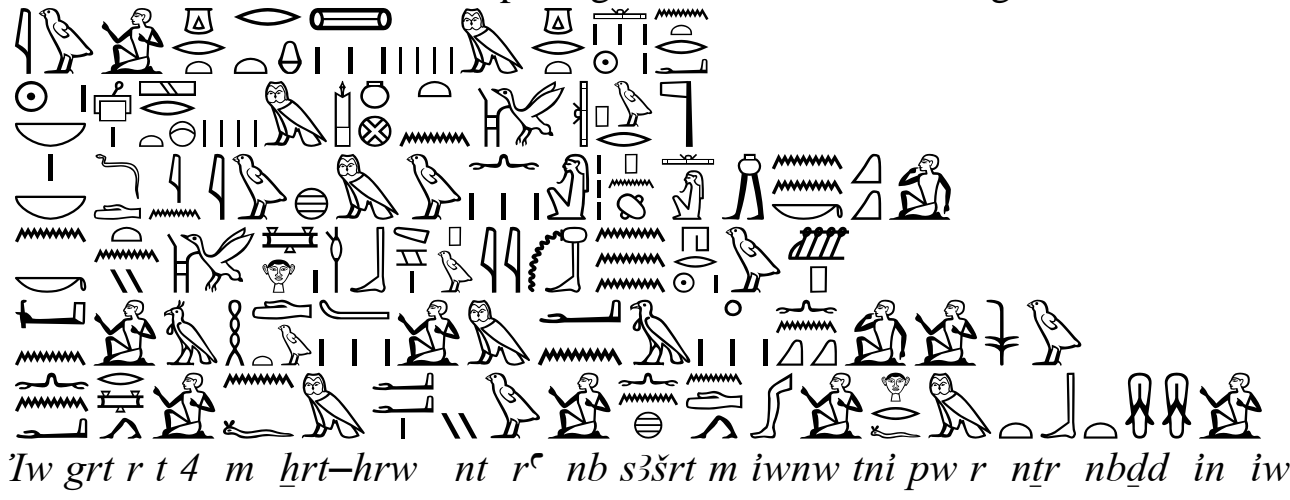




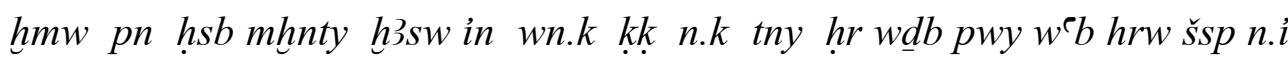
nhd.w.t $m$ `ntyw nn kk.i sw nn `r.i n.f $m$ ๔ wy.i nn hnd.i hr.f $m$ tbwt.y .$i^{(9 \overline{8})}$

"four loaves of bread in the morning of every day and cakes from Heliopolis, because I am more outstanding than any other god. At that time, the one who doesn't know how to count (calculate) said: who will get you the food? And upon this pure shore in the morning, I received (took) my teeth with the perfume (ointment). And thus, I will not eat it and I will not touch it with my hand or step on it with my sandals. ${ }^{(99)}$

Before ending up, the passages of the chapters of the Book of the Dead, we should not ignore chapter 125 of the Book of the Dead that referred the previous meanings with a new addition, as the deceased owning the white teeth is attributed to the land of the lake (Fayoum) in Egypt. To give this meaning, it refers to the following ${ }^{(100)}$ :

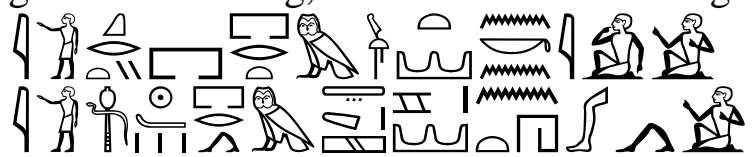

'PI krty pr mimnt $n$ kni II hd ibhw pr $m$ t3-š $n$ thi

"O dweller of caves exiting (attributed) to the west, I was not angry. O

Owner of the white teeth coming from the lake (Fayoum), I have not breached the law ${ }^{(101)}$. 


\title{
Conclusion
}

\author{
Some words expressed teeth like the word S l I libhw, the word

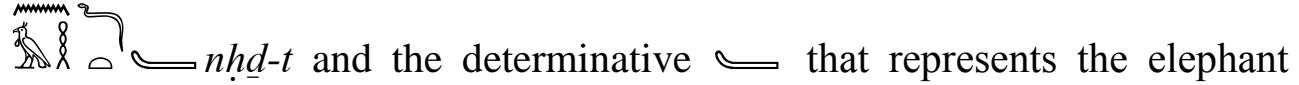 \\ tusk.
}

Elephant and hippopotamus tusks and pieces of ivory were used since the era of Naqqada I in preserving make up and drugs. They could be extracted from the environment surrounding the Ancient Egyptian. Scientists suggested that magicians and dancers used these substances in their rites.

The symbolism of teeth varied in religious texts like pyramid texts, where teeth were presented with onion offering, so that the deceased through them can retrieve the life cycle and renew it, with the smell of onion and presentation of teeth.

The deceased was described as having sharp teeth like Soped. This role is related to his role as a protective god. He is an Asian god protecting the Eastern region and border areas, like turquois mines in Sinai. Thus, the deceased writes the same characteristics. In addition, the deceased was proud of that he has strong teeth that enable him to break stone. He was granted this strength by smelling the perfume of goddess $i h t-w t t$ who helped him (with her scent) to possess the special power to break stone and move from one place to another in the hereafter.

The deceased was embodied more than one time in the Osirian image to be granted the strong solid teeth of Horus. His teeth represented the "ba" souls. He said the strength of his teeth and canines was because they come from the hereafter, from the viper " $\underline{d} w . f t$ ".

In addition, the deceased practices special rites when he receives his teeth, where he revolves around them with an arrow. Some scientists like "Mercer" think it is a game, the game of twining like the snake " $m h n "$ ".

Teeth had important symbolism and significance in coffin texts, where the deceased was granted strong teeth of flint coming from the viper mountain $\underline{d} w . f t$. He was also granted sharp teeth from star metal, signifying their extreme power and holiness.

His strong teeth and sharp canines enabled him to take the image of the god "Sobek". He described himself being free of evils, cleanser of the mouth and hater of evils "isft".

In the book of the dead, the same previous concepts were repeated on a large scale. It affirmed ownership of flintstone teeth coming from the viper mountain " $d w . f t$ ". It gave reason for owning sharp teeth that they are like the teeth of goddess "srkt", and sharp canines like canines of holy Isis.

In addition, the idea was affirmed in coffin texts as to his possession of teeth of snake god " $m h n$ ". He received teeth in a festive way, with the ointment or perfume. He gave reason for his white teeth and their glitter to his being a member of Fayoum city. Hence, he affirmed the affiliation of his teeth to the protective gods and gods that have sharp teeth, being embodied as the snake or viper, so that his canines are scary, sharp and deterrent to enemies. 
كان الفم من أهم أعضاء الجسم بسبب حصوله عله على الطعام و الثشراب و والكلام

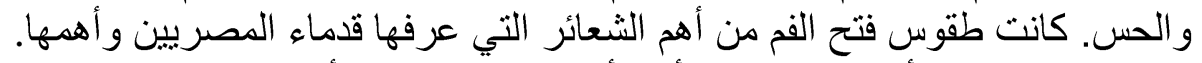

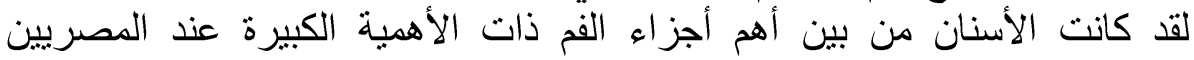

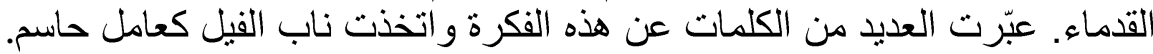

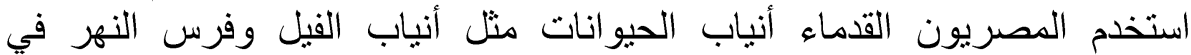
صناعات مختلفة مثل التمائم و المكياج و الأدوية البدائية.

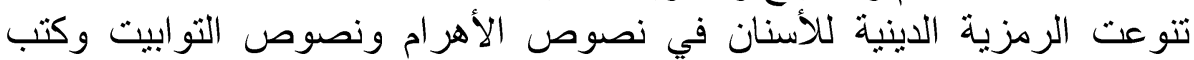

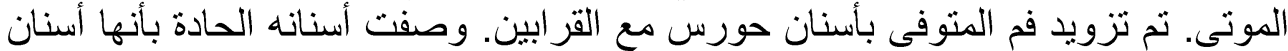

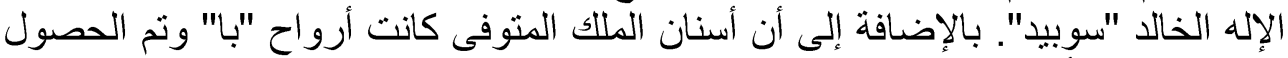

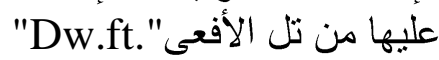

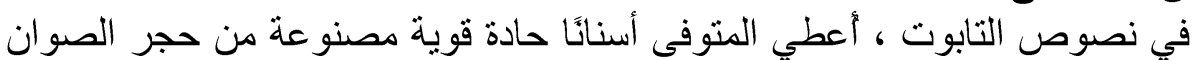

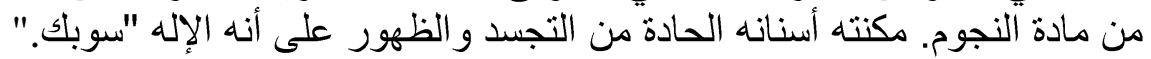

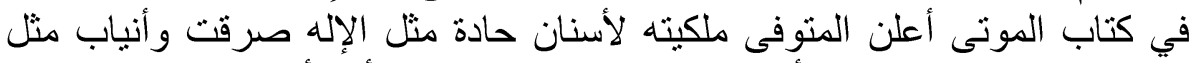
الإلهة المقدسة إيزيس. اللمعان في أسنانه وجمالها يعود إلى كونه أحد أفر اد مدينة الفيوم. الفيان

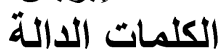
الفم- الاسنان- نصوص الهرم- نصوص التابوتـ كتاب الموتى- صرقتـ ايزيس

\section{References}

${ }^{1}$ Raven , M.J." Egyptian Concepts on the Orientation of the Human body “, JEA 91 , 2005,pp. 37-39 ; Walker , J., studies in Ancient Egyptian Anatomical Terminology, Warminster, 1996 , p. 48 , pp. 91 - 105 ; Lefébvre, G., "Tableau des Parties du Corps Humain mentioreé par Les égyptiens", SASAE 17 , 1952 , pp. 4-5 ; Birch, S., “ Medical Papyrus with the name chepos ", ZÄS 9, 1871, p. 61 .

${ }^{2}$ Westenforf , W., “ Mund” LÄ IV , 1982 , Col.222-223 ; Junge , F. \&Belmer , H., "Language " Oxford . Enc II (2001), pp. 258 -259

${ }^{3} \mathrm{~Wb}, \quad \mathrm{I}, 300(7)$

${ }^{4}$ Toyler, T., A mummy, London, 1995 . p. 67.

${ }^{5}$ Ibid , p. 68 ; Budge , W., Egyptian Magic , London, 1975 , p. 192.

${ }^{6}$ EL mahdy, G., Mummies, Myth and Magic in Ancient Egypt, New York, 1993 , p. 113.

${ }^{7}$ Pinch, G., Magic in Ancient Egypt , London, 1994 , p. 152 .

${ }^{8}$ Grieshammer , R., “ Mund öffnung ritual " LÄ IV , 1982, col. 223 ; Flimm,K., Pharos und Karlsruhe, 2002 , p. 3.

${ }^{9}$ Vercoutter , J “ Apis “ LÄ I , 1975 , cols . 341-342.

${ }^{10}$ Blackman \&Fairman , H.W., " the Conservation of An egyptian Temple according to the use of Edfou “, J EA 32 , 1946 , pp. 75 - 91 .

${ }^{11}$ Lesko, E.L., A Dictionary of Late Egyptian, Fall River, 2002 , p. 259.

${ }^{12} \mathrm{WbII}, 391$.

${ }^{13} \mathrm{~Wb}$ II , 382 , 6, Grapow , H., Anatomie und physiologie , London , 1954 , p.39 , Hannig , R., Großes Handwörterbuch Ägytisch - Deutsch, Mainz, 1995 , p.454.

For more about keywords about mouth view:

Gardiner , A., The Egyptian word for “ Herdsman “, ZÄS 42, 1905 , p. 123 . Urk IV , 406

; Venus , P., " un Formule des shouabtis un Pesudo - naos de La XIII dynastie “, RdE 26 , 1974 ,p.109 Simpson , W., "The Stela of Amun - Worse Governor of Upper Egypt in the 
Reign of Ammenemes I or II “ JEA 51 , 1965 ,p. 65, pl.XIV 1:10 , cheveraeu , P., “ Prosographie des Cards Militaries “ RdE 38 , 1978 ,p. 40 ; Vandier, J., Mo calla :La Tombe d'Ankhitifi et La Tombe de Sebekhotep “IFAo 18 , 1950 , p. 242 , Gardiner , A., the Coronation of King Haremhab “, JEA 39 , 1953 , pl.II .

${ }^{14} \mathrm{~Wb}, \mathrm{IV}, 99,13$, Shilchting, H., "Lippen “ , LÄ III , 1980 , col. 1056.

Also view: Nunn, J. F., Ancient EgyptainMedicine , London , 1996 , p. 169 ; Week , R., Ancient Egyptian Dentistary, Chicago , 1980 , p. 103 . De Buck , A., Egyptian Reading Book ( Exercises and Middle Egyptain Texts , Leiden , 1948 , p. 95 ; Simpson , W.K., The Literature of ancient Egypt , Cairo , 2003 , p. 35

${ }^{15} \mathrm{~Wb}, \mathrm{VI}, 545(1)$

${ }^{16} \mathrm{~Wb}$, II , 320(8) ; Hannig , R., Großes Handwörterbuch , p.430 ; Lesko , L., A Dictionary of Late Egyptian , I, p. 247 .

${ }^{17}$ Wb , I, 64,3, ; Westendorf, W., “ Zahn “ L Ä VI , 1986 , col. 1319 ; Lesko , L., A Dictionary of Late Egyptian, I, p. 24

${ }^{18} \mathrm{~Wb}, \mathrm{II}, 304(5)$;Westendorf, W., “ Zahn “ L Ä VI, 1986, col. 1319.

${ }^{19}$ Gardiner , A., E.G. , 1973 , p. 463 .

${ }^{20} \mathrm{~Wb}, \mathrm{~V}, 409,(9)$.

${ }^{21}$ Petrie , W.M.F., Prehistory Egyptian Carvings , Man , 1902 , p. 33f , pl. XXXII- XXXIII.

${ }^{22}$ Ibid , p. 34 ; Capart , J., Primitive Art in Egypt, London , 1905 , p. 76 ; Ayrton , E., and Loat, W., El Mashana , London ,1911 , p. 29 ; Sharff, A., Die Altertümer der Vor - und Frühzeit Agyptens II , Berlin, 1929, S., 87 .

${ }^{23}$ Ibid , pp. 14-17 ,25 , 27,30,33, pl. XXXII- XXXIII .

${ }^{24}$ Morgan , De Recherches sur Les Origines de L'Egypte , II , Paris , 1897 , p. 63 ; Hornblower, G.D., " Some predynastic Carvings “, JEA XIII , 1927 , p. 243.

${ }^{25}$ Randalle - Maclver , D., \& mace , A., \& Griffith , F., EL Amarah and Abydos , EEF 23 , London, 1902 , p. 48 , p. VII , 2 .

${ }^{26}$ Petrie, W.M.F., Prehistory Egyptian Carving, p. 7 .pl. I 1-8 .

${ }^{27}$ Capart , J., Primitive Art in Egypt , London , 1905 , fig. 155. Scharff , A., Alterümer , II , Berlin, 1929 , S. 28 , taf. $10 \mathrm{Nr} .45$.

${ }^{28}$ Petrie , W.M.F., Prehistory Egyptian Carving, p.9 .

${ }^{29}$ PT $45(35, \mathrm{a})$.

${ }^{30}$ Carrier , C., Textes Des Pyramides de L'Egypte Ancienne, Tome IV , Textes des Pyramides de Merenre d 'Aba , de Neit d' Ipout et d' oudjebten, Cybele , 2010 , Aba /F/N/Med I , 23-30 ,p. 2118.

${ }^{31}$ Allen , J.P., The Ancient Egyptian pyramid Texts, Society of Biblical Literature , Atlanta , 2005 , W33 , Faulkner , R.O., AEPT , p. 9 , Mercer , A.B., The Pyramid Texts , London , 1952 , p. 28

32 Onion:

Egyptians saw a good omen in it in some feasts, in addition to being used to revive the dead. There were three kinds presented in offerings: leek, garlic and onion. They were widely consumed. Offering onion balls was very little in the divine rite, but it was usual in dead rites since the era of pyramids where there was a decorated ribbon of onions around the neck in the feast of soker only green onions were eaten from it on other famous occasions. It is also mentioned in medical papyri. It could also be used in magic. View:

Derchain , ph., "Zwiebel “ L ̈̈, cols 1435 - 1436 ; Roth , A.M., The Pš̌- $k f$ and theOpening of the Mouth Cermony, Aritual of birth and rebirth, JEA 78, 1992 , p. 122 .

${ }^{33}$ Roth , A.M., The Pš̌- $k f$ and theOpening of the Mouth Cermony, Aritual of birth and rebirth , JEA 78,1992 , p. 121 .

${ }^{34}$ Hassan, S., Excavations at Giza, Vol. V, Cairo , 1933, p.103 .

${ }^{35}$ Barta , W.,” Das Opferritual im TäglichenTempelKult “, in JEOL 19, 1967 , p. 70 . 
${ }^{36}$ Ghalioungui , P., \& Others , Food the Gift of Osiris , vol. 2 , London, 1977 , p. 662.

${ }^{37}$ PT 125 ( 79a-b) .

${ }^{38}$ Carrier, C., Textes Des Pyramides de L'EgypteAncienne, TomeVI , Cybele , 2010 , Aba /F/N/Mod III , 13-23 ,p. 2132.

${ }^{39}$ Allen , J.P., The Ancient Egyptian pyramid Text, Society of Biblical Literature , Atlanta , 2005 , W87, Faulkner, R.O., AEPT , p. 26 , Mercer , A.B., The Pyramid Texts , p. 43.

${ }^{40}$ god Mhnty-irty: is one of the gods that took the shape and form of the falcon in Ancient Egypt and it was a main god for the area of"Atrib" and"Koos" view:

Schott, S., "Der Gott Das Harfen spiels " Mélange Maspero , I , orient , Ancien , MIFAO LXVI , 1935 - 1938 , S. 463 ; Brunner , E., " Spitzmaus und Ichneumon alsTiere des Sonnengottes , NAWG 7 , 1965 , SS. 133, 153 - 157.

41 he is one of the Asian gods and was worshipped in the east of Delta in the area of "Saft el Henna" near Zagazig. He appears in two natures resembling Horus and also appears in the human form as a god for Egypt's eastern gate.

LÄGG , VI , 279-281 ; Wilkinson , R., The Complete Gods and Goddesses of Ancient Egypt , London , 2003 ,p. 211 ; Yoyotte , J., Le roi Mer - djefaRê et La dieu Sopdu , un Monument de La XIV edynastie BSFE 114 , Avrill, 1989 , pp.17 - 63 .

${ }^{42}$ PT 215 (148a-d ).

${ }^{43}$ Carrier, C., Textes Des Pyramides de L'Egypte Ancienne, Aba /F/N/e , 11-14 ,p. 2154.

${ }^{44}$ Allen , J.P., The Ancient Egyptian pyramid Text, , W148, Faulkner, R.O., AEPT , p. $42-$ 43 , Mercer, A.B., The Pyramid Texts , p. 60-61.

${ }^{45}$ PT 222(201a-d ).

${ }^{46}$ Carrier , C., Textes Des Pyramides de L'Egypte Ancienne, TomeVI , Cybde , 2010 ,Aba /F/N/e , 45-46,p. 2180 .

${ }^{47}$ Allen , J.P., The Ancient Egyptian pyramid Text, , W155, Faulkner , R.O., AEPT , p. 49 , Mercer, A.B., The Pyramid Texts , p. 67.

48 LÄGG , VI , SS.279-281 ; Wilkinson , R., The Complete Gods and Goddesses of Ancient Egypt , , 211 ; Yoyotte , J., Mer - djefa Rê et La dieu Sopdu , un Monument de La XIV edynastie BSFE $114,1989,17-63$.

${ }^{49}$ PT $436(790 \mathrm{~b}-791 \mathrm{c})$.

${ }^{50}$ Carrier , C., Textes Des Pyramides de L'Egypte Ancienne , TomeIV ,Aba /F/N/e , inf 1-4 , p. 1896 .

${ }^{51}$ Allen , J.P., The Ancient Egyptian pyramid Text, , p.30, Mercer , A.B., Pyramid Texts , p. 67 .

${ }^{52}$ Mercer , A.B., Pyramid Texts , Commentar , vol.II , p. 396 (791 a ), CT 67 ( 285 ,g ) $\mathrm{Wb}, 125$ (10)

${ }^{53} \mathrm{Ba}$ as a spiritual element and its roles view:

Zabkar, L., a study of the Ba Concept in Ancient Egyptian Texts , Chicago , 1968 , De Cenival , J., Le Livere pour Sortier Le Jour, Paris , 1992 , p. 21-22 ; Hayes , W.C., The Sceptre of Egypt , I , 1935 , p. 79 ; Kees , H., Totenglauben und JenseitsVorstellungender altenAgypten , Berlin , 1956 , pp. 58-66 ; Otto , E., Die biedenVoglestaligen Seilen Vorstellungen der Agypter, ZÄS LXXVI , 1942 , p. 8 .

${ }^{54}$ PT $539(1306 \mathrm{~b}-1307 \mathrm{a})$.

${ }^{55}$ Carrier , C., Textes Des Pyramides de L'EgypteAncienne , TomeII , Cybele , 2009 ,P /V/S, 1-3, p. 1026 .

${ }^{56}$ Allen, J.P., The Ancient Egyptian pyramid Texts, , p.486, Faulkner, R.O., AEPT , p. 206

; Mercer, A.B., The Pyramid Texts , p. 214.

${ }^{57}$ The bread offering:

Bread was one of the main meals that Egyptians are keen on where it was used in funereal rites and rites of daily service and festivals. It was also related to life and its cycle. For more, view: 
Warsham , ch.E.," Areinterpretation of 5the So - Called Bread Loaves in Egyptian Offering Scenes “, JARCE 16, 1979 , p. 7-10 ; Spalinger , A., " Backing During the Reigen of Sethi I “ , BIFAO 86,1986, pp.316ff.

58 Beer:

Beer is soaked bread and barley yeastthat is mixed with aromatic plants

Helck , W., "Bier” , LÄ I , col790-791 ; id., Das Bier imAltenAgypten , Berlin , 1971 , pp. 19,25 .

${ }^{59} d w . f t$ mountain

Is a mountain of viper a kind of snakes in the sandy desert and represents the sixth nome of Upper Egyptian nomes. Wb V , 545(6) .

${ }^{60}$ PT $553(1357 \mathrm{a}-1359 \mathrm{c})$.

${ }^{61}$ Carrier , C., Textes Des Pyramides de L'Egypte Ancienne, Tome III ,Textes de La Pyramides de pepi II , Cybele , 2010 ,N /V/E, 1-4 , p. 1750 .

${ }^{62}$ Allen , J.P., The Ancient Egyptian pyramid Text, , p.526, Faulkner , R.O., AEPT , p. 213 ; Mercer, A.B., The Pyramid Texts , p. 220.

${ }^{63}$ PT 659 (1864b -1867a ).

${ }^{64}$ Carrier , C., Textes Des Pyramides de L'EgypteAncienne , TomeIII , Cybele , 2010 ,N /F/E, n 14-15, p. 1350 .

${ }^{65}$ Allen , J.P., The Ancient Egyptian pyramid Text, , N.357, Faulkner , R.O., AEPT , p. 271

; Mercer, A.B., The Pyramid Texts , p. 279.

${ }^{66} \mathrm{~Wb}, \mathrm{~V}, 222(2)$.

${ }^{67} \mathrm{~Wb}$, III, 488(7) .

${ }^{68}$ Mercer, A.B., The Pyramid Texts ,Commentary , p. 851( 1866,b) .

${ }^{69}$ CT 173 (CT54b-9) .

${ }^{70}$ Carrier , C., Textes des Sarcophages du Moyen Empire Égyptien, Tome I, Spell [1 ]á( 354) ; Rocher, 2004, CT III54( b -g), p. 428 .

${ }^{71}$ Faulkner, R.O., AECT , p. 148 .

${ }^{72} \mathrm{CT} 342$ (CT VI $346 \mathrm{k}-347 \mathrm{e}$ ).

${ }^{73}$ Carrier , C., Textes des Sarcophages du Moyen Empire Égyptien , Tome I , CT IV , 346 k -347 e , p. 852 .

${ }^{74}$ Faulkner, R.O., AECT , p. 276.

${ }^{75}$ CT 666 ( CT VI 294m-q).

${ }^{76}$ Carrier , C., Textes des Sarcophages du Moyen Empire Égyptien, Tome II , Spell (355a), (787), Rocher, 2004, CT VI 293a-294,m , p. 1520.

${ }^{77}$ Faulkner, R.O., AECT , p. 238.

${ }^{78}$ CT 991(CTIII 201e -I ) .

${ }^{79}$ Carrier , C., Textes des Sarcophages du Moyen Empire Égyptien , Tome III , Spell (788a)

, ( 1186), Rocher , 2004, CT VII 201,e-203,i .

${ }^{80}$ Faulkner, R.O., AECT III, p. 99.

${ }^{81}$ about Taboos and forbidding them view:

Frandsen , J.P., “ Taboo”, Oxf. Enc. III , p. 345 ; id., Tabu , LÄ VI , cols 135-138 ; Janssen , J.J., The Menstrual Taboo in Ancient Egypt “ „JNES 66/2 , 2007 , pp. 81-105;Frandsen , J.P., "Bwt Divine Kingship and Grammer “, AKVIÄk, 1985 , pp. 151-158 .

${ }^{82}$ CT 1011(CT VI , 226,d-h) .

${ }^{83}$ Carrier , C., Textes des Sarcophages du Moyen Empire Égyptien , Tome III , Spell (788a)

, (1186), Rocer, 2004, CT VII 226c-h , p. 2142.

${ }^{84}$ Faulkner, R.O., AECT III, p. 111.

${ }^{85}$ BD ,ch XXXI (3-4).

${ }^{86}$ Carrier , C.,Livre de Morts de L' Egypte ancienne , Melchat 2 , Cybele , 2009 , p. 145(34). 
${ }^{87}$ Faulkner, R.O., BD , p. 56 .

${ }^{88} \mathrm{BD}, \mathrm{chX}$ LII (5-7) .

${ }^{89}$ Carrier, C.,Livre de Morts, p. 174(5-7) .

${ }^{90}$ the god $h n t y-h 33 w$ has appeared since the era of the new kingdomand the grecoroman eraand is considered one of the images od god Osiris: wsirhntyh 3sw. View::LÄGG, S. 845

${ }^{91}$ Faulkner, R.O., BD , p. 62 .

${ }^{92}$ LÄGG , VI , 436-440 , Wilkinson , R., The Complete Gods and Goddesses of Ancient Egypt, p. 233 .

${ }^{93}$ the snake $m h n$ : Faulkner explained its name as the twined andit is a sign to the strength (innate within the body of the snake) that enables it to twine many times. Its role is summarized in protecting the god of the sun trough its folds where it plays the role of the strong guard. For more:

Faulkner, CDME , p. 114 ,115 ; Ranke, H., Die Altägyptischen Personennamen , 2 , BdE , Glückstadt , 1935-1952 .

${ }^{94} \mathrm{BD}, \mathrm{ch} \mathrm{XII}$.

${ }^{95}$ Carrier, C.,Livre de Morts, p. 757(16)- 758 (17) .

${ }^{96}$ Faulkner, R.O., BD , p. 171 .

${ }^{97} \mathrm{BD}$,ch L,II, B (17) .

${ }^{98}$ Carrier, C.,Livre de Morts, p. 846 .

${ }^{99}$ Faulkner, R.O., BD , p. 188 .

${ }^{100}$ BD ,ch CXXV , p. 124(11)-128(12).

${ }^{101}$ Faulkner, R.O., BD , p. 32 .

\section{Bibliography}

1. Allen , J.P., The Ancient Egyptian pyramid Text, Society of Biblical Literature , Atlanta , 2005.

2. Ayrton, E., and Loat, W., El Mashana, London ,1911.

3. Barta , W.," Das Opferritual im TäglichenTempelKult “, in JEOL 19, 1967.

4. Blackman , A., " the Rite of Opening of the Mouth in Ancient Egypt and Bayblonia “, JEA 10,1924 .

5. Blackman \&Fairman , H.W., " the Conservation of An egyptian Temple according to the use of Edfou ", J EA 32, 1946.

6. Birch, S., " Medical Papyrus with the name chepos " , ZÄS 9, 1871 , p. 61.

7. Brunner , E., "Spitzmaus und Ichneumon alsTiere des Sonnengottes, NAWG 7, 1965.

8. Budge , W. , Book of the Dead , 3 vols., London, 1910 .

9. Budge, W., Egyptian Magic, London, 1975 , p. 192.

10. Capart, J., Primitive Art in Egypt, London, 1905 .

11. Carrier, C., Textes des Sarcophages du Moyen Empire Égyptien, Tome I-VI, Rocher , 2004.

12. Carrier, C.,Livre de Morts de L' Egypte ancienne, Melchat 2 , Cybele, 2009.

13. Carrier, C., Textes Des Pyramides de LEgypte Ancienne, TomeVI , Cybde , 2010 .

14. cheveraeu, P., " Prosographie des Cards Militaries "RdE 38, 1978.

15. De Buck , A. , The Egyptian Coffin Texts , 7 vols. , Chicago , 1935-1961

16. De Buck, A., Egyptian Reading Book ( Exercises and Middle Egyptain Texts, Leiden , 1948 , p. 95

17. De Cenival , J., Le Livere pour Sortier Le Jour , Paris , 1992 .

18. Derchain, ph., "Zwiebel “ LÄ, cols 1435- 1436.

19. EL mahdy, G., Mummies, Myth and Magic in Ancient Egypt, New York, 1993 .

20. Erman A. \&Grapow H., Wörterbuch der Aägyptischen Sprache , 7 vols , Berlin , 1971

21. Faulkner, R. O., A Concise Dictionary of Middle Egyptian, Oxford, 1962.

22. Faulkner, R.O.,The Ancient Egyptian Pyramid Texts, Oxford, 1969. 
23. Faulkner, R. O. ,The Ancient Egyptian Coffin Texts , 3 vols. , Warminster, 1973 1978

24. Frandsen, J.P., "Taboo" , Oxf. Enc. III , p. 345 ;

25. Frandsen, J.P., "Bwt Divine Kingship and Grammer " , AKVIÄk , 1985 , pp. 151-158 .

26. Frandsen, J.P., Tabu , LÄ VI, cols 135-138 ;

27. Faulkner, R.O., Book of the Dead,

28. Gardiner, A. H. ,Egyptian Grammar, Oxford, 1973.

29. Gardiner , A., the Coronation of King Haremhab " , JEA 39 , 1953 , pl.II .

30. Gardiner , A., The Egyptian word for "Herdsman " , ZÄS 42,1905 , p. 123.

31. Ghalioungui , P., \& Others, Food the Gift of Osiris , vol. 2 , London, 1977.

32. Grapow, H., Anatomie und physiologie, London, 1954, p.39,

33. Hassan, S., Excavations at Giza, Vol. V, Cairo, 1933, p.103.

34. Hannig, R., Großes Handwörterbuch Ägytisch - Deutsch, Mainz , 1995 , p.454.

35. Hayes, W.C., The Sceptre of Egypt , I, 1935 , p. 79 ;

36. Helck, W., "Bier", LÄI, col790-791;

37. Helck, W., Das Bier imAltenAgypten, Berlin , 1971 , pp.19,25.

38. Hornblower, G.D., " Some predynastic Carvings “, JEA XIII , 1927 , p. 243.

39. Janssen, J.J., The Menstrual Taboo in Ancient Egypt ",JNES 66/2 , 2007 , pp. 81-105;

40. Junge, , F. \&Belmer, H., "Language “ Oxford . Enc II (2001) ), pp. 258 -259

41. Kees, H., Totenglauben und JenseitsVorstellungender altenAgypten, Berlin , 1956.

42. Lexikon der Ägyptischen Götter und Götterbezeichungen, I-XI, 2002.

43. Lesko, E.L., A Dictionary of Late Egyptian, Fall River, 2002.

44. Lefébvre , G., "Tableau des Parties du Corps Humain mentioreé par Les égyptiens", SASAE 17,1952 , pp. $4-5$;

45. Mercer, A.B., Pyramid Texts , Commentar, vol.II .

46. Morgan, De Recherches sur Les Origines de L'Egypte, II , Paris, 1897.

47. Nunn, J. F., Ancient EgyptainMedicine, London, 1996.

48. Otto , E., Die biedenVoglestaligen Seilen Vorstellungen der Agypter, ZÄS LXXVI , 1942.

49. Petrie, W.M.F., Prehistory Egyptian Carving, Man , 1902.

50. Pinch, G., Magic in Ancient Egypt, London, 1994 , p. 152 .

51. Randalle-Maclver, D., \& mace, A., \& Griffith, F., EL Amarah and Abydos , EEF 23 , London, 1902 .

52. Raven, M.J." Egyptian Concepts on the Orientation of the Human body ", JEA 91 , 2005.

53. Roth, A.M., The Psš- $k f$ and theOpening of the Mouth Cermony, Aritual of birth and rebirth, JEA 78,1992 , p. 121 .

54. Ranke, H., Due Altägyptischen Personennamen , 2 , BdE , Glückstadt , 1935-1952 .

55. Schott, S., "Der Gott Das Harfen spiels "Mélange Maspero, I, orient, Ancien, MIFAO LXVI, $1935-1938$.

56. Schurf, A., Alterümer , II , Berlin , 1929 , S. 28 , taf. 10 Nr 45 .

57. Sethe,K., Urkunden der Altägyptischen Allertums, Leipzig , 1914.

58. Sethe.k., Die AltägyptischenPyramidentexte, 4 Bde, Leipzig 1908-1922.

59. Sharff, A., Die Altertümer der Vor - und Frühzeit Agyptens II , Berlin , 1929 , S., 87 .

60. Shilchting , H., "Lippen " , LÄ III , 1980, col. 1056.

61. Simpson, W.K., The Literature of ancient Egypt, Cairo, 2003 , p. 35

62. Spalinger , A., " Backing During the Reigen of Sethi I ", BIFAO 86, 1986.

63. Simpson, W., "The Stela of Amun - Worse Governor of Upper Egypt in the Reign of Ammenemes I or II "JEA 51, 1965. 
64. Toyler, T., A mummy, London, 1995 .p. 67

65. Vandier, J., Mo'alla :La Tombe d'Ankhitifi et La Tombe de Sebekhotep "IFAo 18 , 1950 .

66. Venus, P., " une Formule des shouabtis un Pesudo - naos de La XIII dynastie ", RdE 26,1974 .

67. Vercoutter, J " Apis " LÄ I , 1975, cols . 341-342.

68. Walker , J., studies in Ancient Egyptian Anatomical Terminology , Warminster , 1996.

69. Warsham , ch.E.," Areinterpretation of 5the So - Called Bread Loaves in Egyptian Offering Scenes “, JARCE 16, 1979 , p. 7-10 ;

70. Week, R., Ancient Egyptian Dentistary, Chicago , 1980 , p. 103 .

71. Westendorf, W., "Zahn " L Ä VI , 1986, col. 1319 ;

72. Westenforf, W., “Mund” LÄ IV , 1982 , Col.222-223 ; J

73. Wilkinson, R., The Complete Gods and Goddesses of Ancient Egypt , London , 2003.

74. BSFE 114 , Avrill, 1989 , pp.17 - 63 .

75. Zabkar, L., a study of the Ba Copcept in Ancient Egyptian Texts, Chicago, 1968 , 